ポリエチレンフィルムの横方向への延伸における結晶相の狍向挙動

藤森工業株式会社研究所高橋 亨・佐藤一郎

\title{
DEFORMATION PROCESSES OF POLYETHYLENE IN THE STRETCHING TO THE DIRECTION PERPENDICULAR OF FILM INTERPRETED IN TERMS OF CRYSTAL ORIENTATION
}

By Tōru Takahashi, Ichirō Satō

(Research Department, Fujimori Kogyo Company Ltd. 56, Imai

Kami-Cho, Kawasaki-City, Kanagawa Prefecture, Japan)

Orientation behavior of crystalline phase in the uniaxial stretching of tubular extruded polyethylene film in the direction prerpendicular to the machine direction is discussed quantitatively in terms of the $\mathrm{X}$-ray pole figure and the degree of biaxial orientation functions.

In the stretching the following deformation processes are recognized:

(1) The screw axis of lamellar texture shifts to the stretching direction. The order of orientation distribution of $b$-axis about the screw axis is still kept up at the displacement of the screw axis.

(2) The shifting of screw axis is attended by $a$-, $c$-axes rotation about $b$-axis. And the value of biaxial orientation functions $\overline{\cos ^{2} \Phi_{c, y}}$ and $\overline{\cos ^{2} \Phi_{a, x}}$ is recognized to increase gradually.

The crystal $c$-axis becomes, finally, almost parallel to the stretching axis and $a$-, and $b$-axes take optionally rotating orientation in the perpendicular direction to $c$-axis.

(Received November 26, 1969)

\section{1. 緒言}

高密度ポリエチレンのインフレーションフィルムを第 I図のように，その成型方向に対乙て直角方向入熱延伸 するとき，あるいは $c$ 軸高配向ポリエレンフィルムをそ の直角方向へ熱延伸寸るとき，その引張り力はせえ断力 に分解する。ポリェチレンフィルムの結晶相の跬性举動

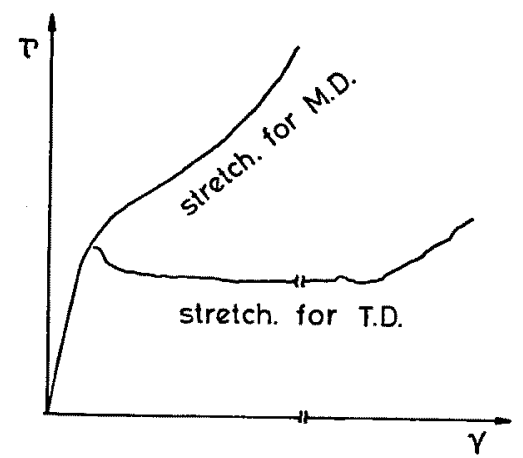

Fig. 1. Schematic diagram of Load-Elongation curves of tubular extruded polyethylene film in the two stretching systems.
を理解し，結晶回転によって生ずる集合組織の発生の過 程を直観的，定珄的に見ようとしたるのである。検討は 極図形と二軸配向係数の観点から行なった。二軸配向係 の取扱い力は Wilchinsky'), Desper and Stein ${ }^{2)} ら の$ 報告に従った。

\section{2. 実験}

\section{$2 \cdot 1 \mathrm{X}$ 楾回折によるボリエチレン結晶の $\boldsymbol{a}, \boldsymbol{b}, \boldsymbol{c}$ 軸} の 2 軸配向性の評価

第 2 図のような単位球を考え, 方向べトル $O N$ と測 定しよらとする空間の特定 2 軸 $O z, O y$ とのなす角度を それぞれ $\Phi$ (極角)， $\Psi$ (方位角) とすると方向へクトル $O N$ の球面での分布图数は $N_{\left(\Phi_{x}, \Psi_{z}\right)}$ である。縃ての $\Phi_{x}$,

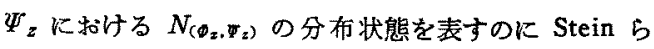
は第3図に示したような $\Phi_{x}, \Phi_{y} ， \Phi_{z}$ の関係を用い，三 つの $\overline{\cos ^{2} \Phi_{i}}$ の組合わせにより示した。それらは式 1〜 3 に上り嵮出される。

$$
\frac{\cos ^{2} \Phi_{x}}{x}=\frac{\int_{0}^{\pi / 2}\left[\int_{0}^{\pi} N_{\left(\Phi_{x}, \Psi_{z}\right)} d \Psi_{z}\right]_{\phi_{x}} \cos ^{2} \Phi_{x} \sin \Phi_{x} d \Phi_{x}}{\int_{0}^{\pi / 2}\left[\int_{0}^{\pi} N_{\left(\varphi_{x}, \Psi_{z}\right)} d \Psi_{z}\right]_{\phi_{x}} \sin \Phi_{x} d \Phi_{x}}
$$




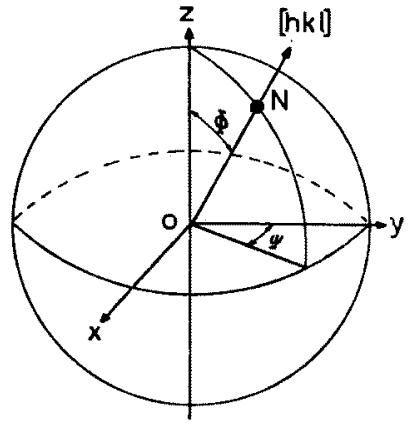

Fig. 2. Position of plane normal $N$ located by spherical coordinates $\Phi$ and $\Psi$.

Inflation D. or First stretch.D.

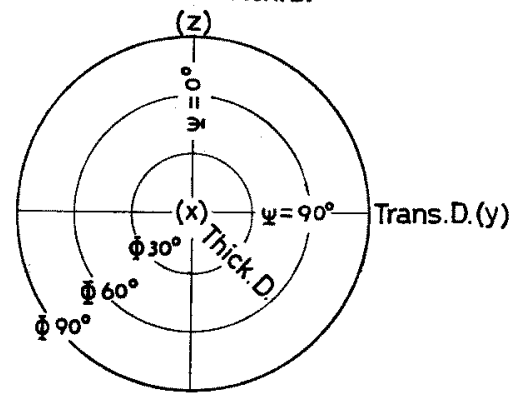

Fig. 4. Location of polar angle $\Phi_{x}$ and azimuthal angle $\Psi_{z}$ shown in pole figure.

Fig. 5. Explanation for the test specimens used. (Exprerimental material :

Tubular extruded film)

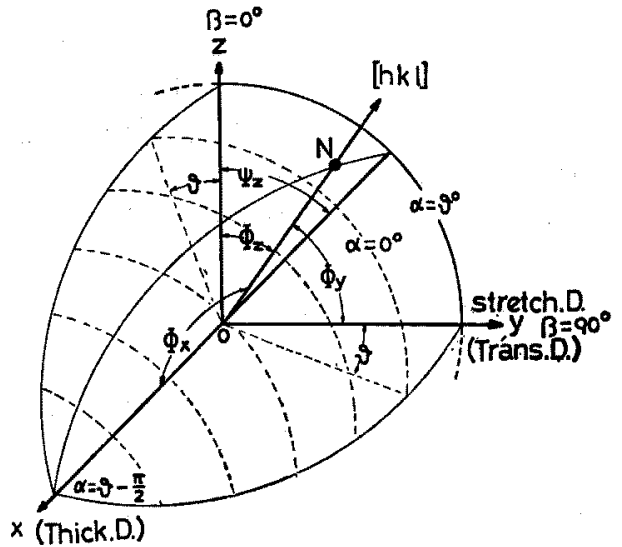

Fig. 3. Orientation of the [hkl] normal for the crystallites and location of $\Phi_{x}, \Phi_{y}, \Phi_{z}$.
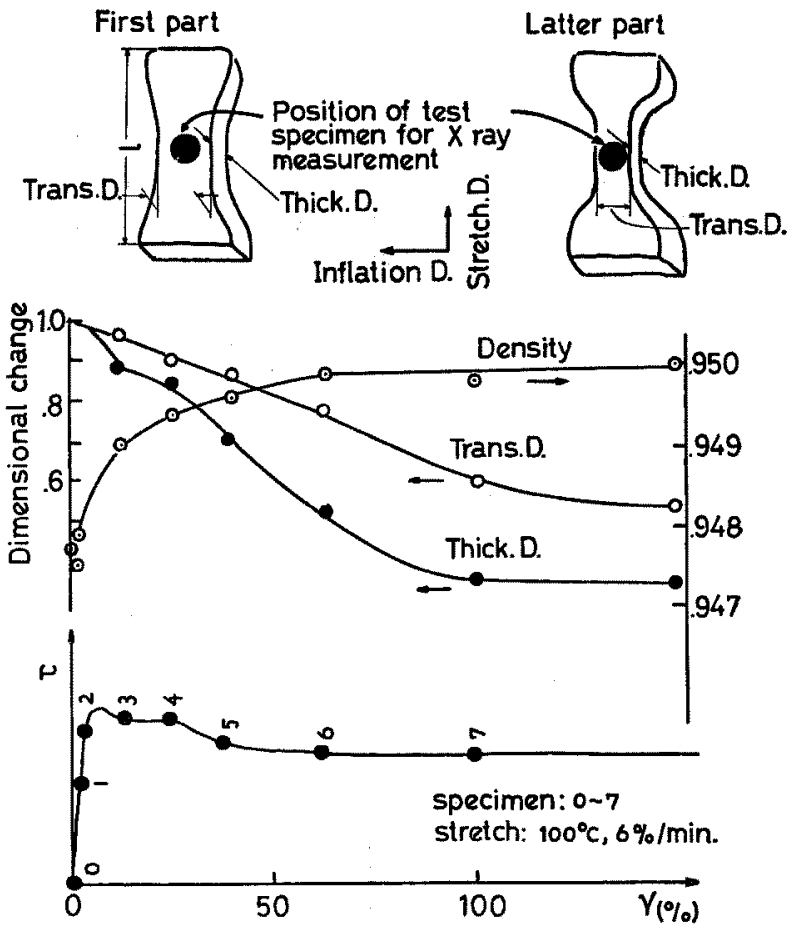

$$
\begin{gathered}
\overline{\cos ^{2} \Phi_{z}}=\frac{\int_{0}^{x / 2} \int_{0}^{\pi} N_{\left(\Phi_{x}, \Psi_{z}\right)} \sin ^{3} \Phi_{x} \cos ^{2} \Psi_{z} d \Psi_{z} d \Phi_{x}}{\int_{0}^{\pi / 2} \int_{0}^{\pi} N_{\left(\phi_{x}, \Psi_{z}\right)} \sin \Phi_{x} d \Psi_{z} d \Phi_{x}} \\
\overline{\cos ^{2} \Phi_{x}}+\overline{\cos ^{2} \Phi_{y}}+\overline{\cos ^{2} \Phi_{z}}=1
\end{gathered}
$$

$\Phi_{x}, \Psi_{z}$ の角度のとり方は第 4 园汇示した。ある極角 $\Phi_{x}$ に战ける分布函数 $N_{\left(\omega_{x}, w_{z}\right)}$ は

$$
N_{\left(\Phi_{x}, W_{z}\right) \psi_{x}} d \Psi_{z}=K I_{(\alpha, \beta)} \alpha \beta
$$

で求めた。 $K$ は比例定数であり， $I_{(\alpha, \beta)}$ は $x$ 軸と入射 $\mathrm{X}$ 線との間の傾斜角 $\alpha$ を一定に保った状態で走查角を市る $2 \vartheta$ に保らながら求めたX線方位 $(\beta)$ 強度分布であり, この場合, 陚料は $\alpha=5^{\circ}$ ステップ每に $\beta=0^{\circ}$ 加 $90^{\circ}$ ま

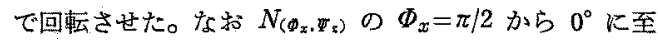
る分布はX線透過回折法3) と反射回折法 (シュルッ法(1)) 
を組合わせることにより求めた。

結晶三主軸の配向分有の㵋定は (200)，(020）回折を 用いて直接 $a, b$ 軸の配向を，また $c$ 軸の配向を式 5 K よって求める方法と，(200）回折から直接 $a$ 軸配向を求 め [110] および [200]の $\overline{\cos ^{2} \Phi_{i}}$ の観点から式6を用 いて $c$ 軸配向を求め, さらにb軸配向を式 5 によって求 める方法の選㫢によった。

$$
\overline{\cos ^{2} \Phi_{a, i}}+\overline{\cos ^{2} \Phi_{b, i}}+\overline{\cos ^{2} \Phi_{c}, i}=1
$$

$\overline{\cos ^{2} \Phi_{c, t}}=1$

$-\frac{\left(1-2 \sin ^{2} \rho_{200}\right) \overline{\cos ^{2} \Phi_{110}, t}-\left(1-2 \sin ^{2} \rho_{110}\right) \overline{\cos ^{2} \Phi_{a, \imath}}}{\sin ^{2} \rho_{110}-\sin ^{2} \rho_{200}}$

ここでのは unit cell から求められるところの $a$ 軸と 各逆格子ベクトルのなす角度であり，iは方向べクトル $x, y, z$ を意味する。

\section{$2 \cdot 2$ 摽 料}

フィルムは高密度ポリチレン Hizex $5000 \mathrm{~S}$ であり 厚さ $70 \mu$ にインフレーション法で製膜したものであ る。延伸は $100^{\circ} \mathrm{C}$ に扎いインストロン型オートグラフ により变形速度 $6 \% / \mathrm{min}$ で自由愊一軸延伸を行ない， いろいろなひずみ率を与えた後, 徐冷し，クリップから 取りはずし，第 5 図の上5に引張方向の中央部からX線 回折用試料採取した。一方，同一のインフレーション フィルムを前報らつの方法によってその M.D.へ自由幅で $200 \%$ 菇延伸を行なって $c$ 軸配向フィルムを得，これを 村料として，その横方向へ $100^{\circ} \mathrm{C}$ にて変形速度 $170 \%$

Table 1. Biaxial orientation of three crystallographic axes of polyethylene crystallites in the stretching for transverse direction of tubular extruded film.

\begin{tabular}{c|c|c|c|c|c|c|c|c|c}
\hline \multirow{2}{*}{ Specimen } & \multicolumn{3}{|c|}{$\overline{\cos ^{2} \Phi_{a}}$} & \multicolumn{3}{c|}{$\overline{\cos ^{2} \Phi_{b}}$} & \multicolumn{3}{c}{$\overline{\cos ^{2} \Phi_{c}}$} \\
& $x$ & $y$ & $z$ & $x$ & $y$ & $z$ & $x$ & $y$ & $z$ \\
\hline No. 0 & .306 & 0.231 & 0.463 & 0.473 & 0.480 & 0.047 & 0.221 & 0.289 & 0.490 \\
No. 2 & .312 & .219 & .469 & .473 & .472 & .055 & .215 & .309 & .476 \\
No. 3 & .350 & .143 & .507 & .504 & .422 & .074 & .146 & .435 & .419 \\
No. 4 & .391 & .121 & .488 & .501 & .382 & .117 & .108 & .497 & .395 \\
No. 5 & .459 & .091 & .450 & .497 & .310 & .193 & .044 & .599 & .357 \\
No. 6 & .500 & .045 & .455 & .481 & .082 & .437 & .019 & .873 & .108 \\
No. 7 & .496 & .014 & .490 & .486 & .070 & .444 & .018 & .916 & .066 \\
\hline
\end{tabular}

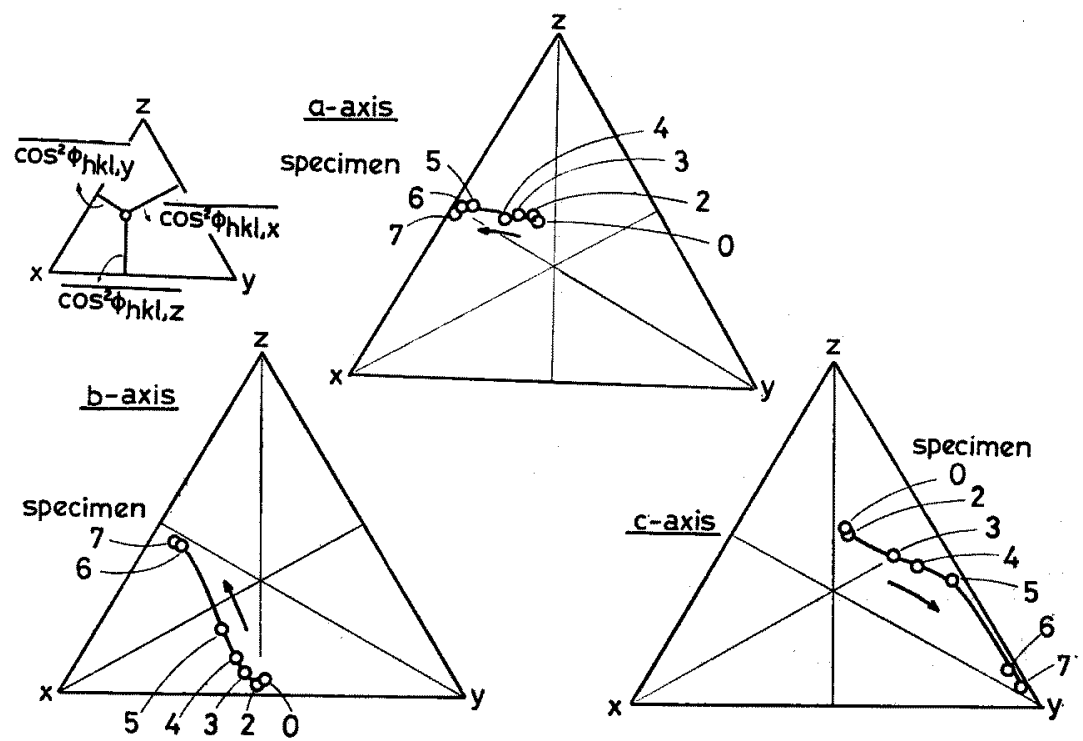

Fig. 6. Equilateral triangle coordinates representing the degrees of biaxial orientations of crystallites in termes of the three quantities of $\overline{\cos ^{2} \Phi_{i}}$. Test Specimens : Tubular extruded $\mathrm{PE}$ film and its stretched films for transverse direction. 
minで自由輻軸延伸を行ない，第5図に示したよらな各 ひずみ率を与克な陚料沉ついてもX線回折実験を誡み た。

\section{3. 実呀轺果およひ考察}

第 5 図の各試料についての二軸配向保数を第工表に， またそんらの正三角形プロットを第6四に示した。第 7-0〜7-7 四にそれらの梗図形を示した。
横方向への引張りは構造要菜に効してせん断応力とな って作用し，試料の变形恃結晶 $c$ 軸の方位の变化を伴 $5 。$ 引張りを試料の雨端に加えると, 試料の変形は第 5 図上部の模式図の上ら起り, 結晶 $c$ 軸のせん断角は試 料の引張り方向各部分で一梾でく，初期方位との間の 傾きの小さい部分（クリップ年近い位置の部分）から大

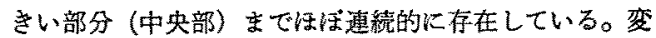
形がすすむにつれて回転社続き， $b, c$ 軸の方立変化は畜

Specimen unstretched film

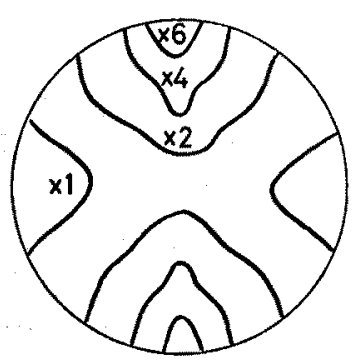

(200)

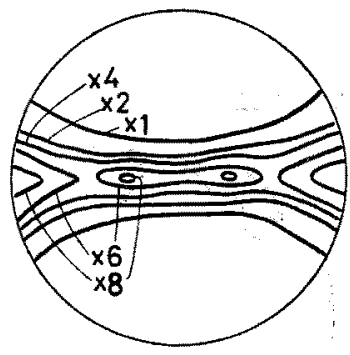

(020)

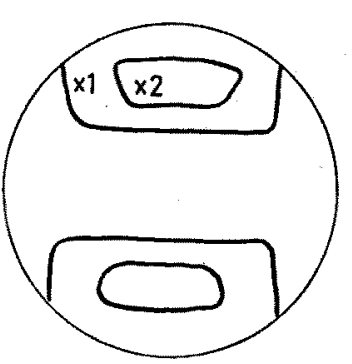

(002)

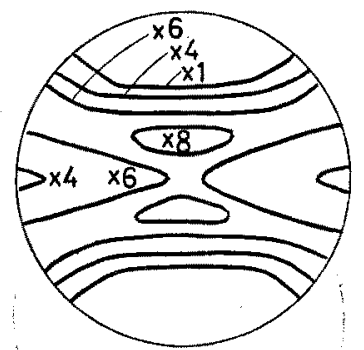

(110)

Fig. 7-0. Pole figures of polyethylene film in the process of stretching for transverse direction.

Specimen No. 1

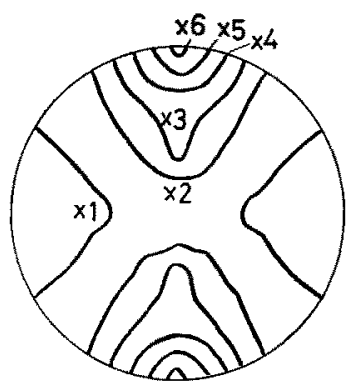

(200)

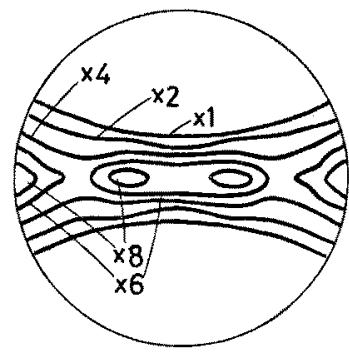

(020)

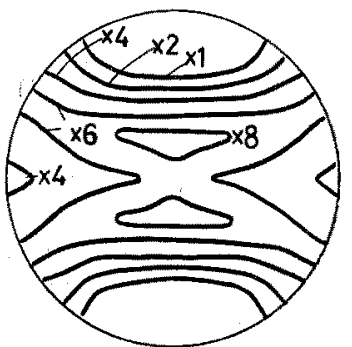

(110)

Fig. 7-1. (continued) 
猜され，試験片 No. 7 に至ると試料中央部の結晶 $c$ 軸の 万位分布の中心は完全に引張り方向に一致し，中央部の 方位変化は終了し，方位分布の巾は減少してゆき，降伏 が全体に和よぶ間，せ九断応力はほぼ一定に保たれる。 この変化際しては $c$ 軸の方位変化に伴って变位すると ころの零った斜めの線すなわち deformation-band 観察することができる。

先にわれわれはインフレーション法で製膜した高密度
ポリエチレンフィルムの M. D. への延伸に際しては, Holmes et. $\mathrm{al}^{6)}$ により提案された“Type-I”あるいはKobayashi7/により提称された"Screw-Dislocation-Model” の結晶集合組織から “Fiber-Type”の集合組織への転 换を認め，延伸による変形の初期段階においては，その 眼界的ヶースとして “Type-I-Model”と“Fiber-TypeModel”との共存を観察し，延伸による变形の進展はこ れら簡単な二つの Model の相対量の変化として説明て

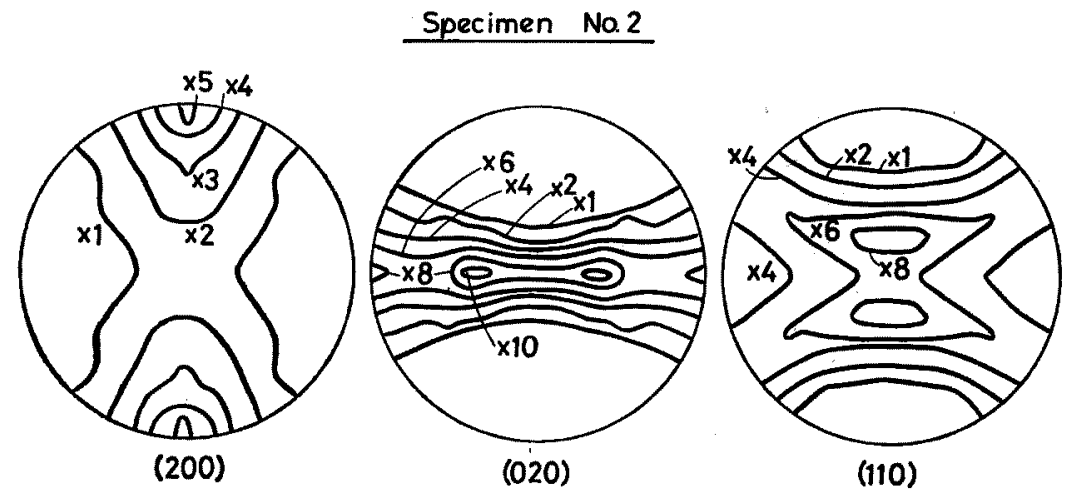

Fig. 7-2. (continued)

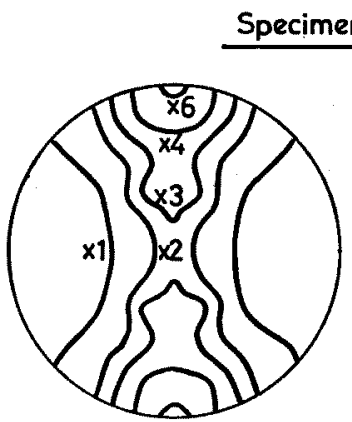

(200)

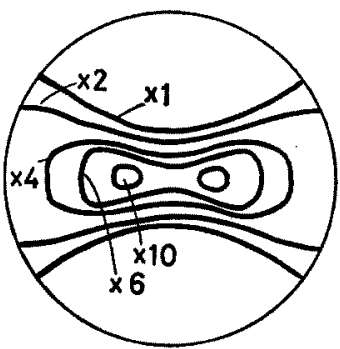

(020)
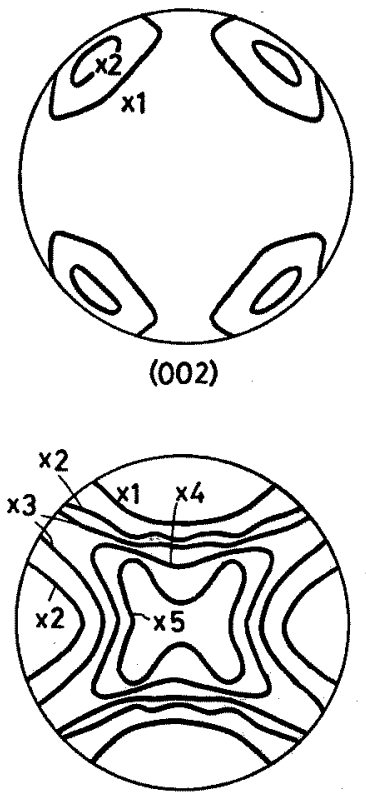

(110)

Fig. 7-3. (continued) 
きることを認め，しかるこの転換は Keller とより提称 された “Type-II-Model” の結晶集合組織の回転関係名) を踏翼することを報向したら。

今回の実験に用いたインフレーション法製膜ポリエチ レンフィルムは第1表に示した結晶配向係数扰よび第7-0 因の極図形を竞，結晶 6 軸の配向は $z$ 軸に平行に配向 したものから， $z$ 軸に対して傾斜して存在するものまで 広く分布して拈り，その分布の相対量は $z$ 軸からの傾斜
角度が大きくなるにつれて少くなる。フィルム法線に対 する平均配向角度 $\overline{\Phi_{x}}$ を式 7 により求めた結果，60. $24^{\circ}$ であった。

$$
\overline{\Phi_{x}}=\frac{\int_{0}^{\pi / 2}\left[\int_{0}^{\pi} N_{\left(\Phi_{x}, \Psi_{z}\right)} d \Psi_{z}\right]_{\emptyset_{x}} \Phi_{x} \sin \Phi_{x} d \Phi_{x}}{\int_{0}^{\pi / 2}\left[\int_{0}^{\pi} N_{\left(\Phi_{x}, \Psi_{z}\right)} d \Psi_{z}\right]_{\Phi_{x}} \sin \Phi_{x} d \Phi_{x}}
$$

このフィルムの横方向への自由幅延伸と揦いては次の二 つの結晶配向変化の莱過程を経ることが珰められた。

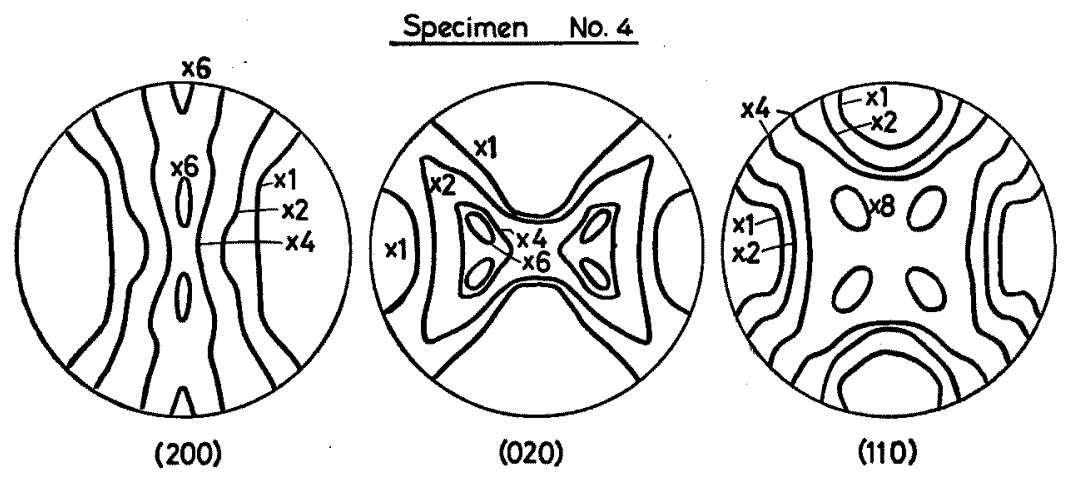

Fig. 7-4. (continued)

Specimen No. 5
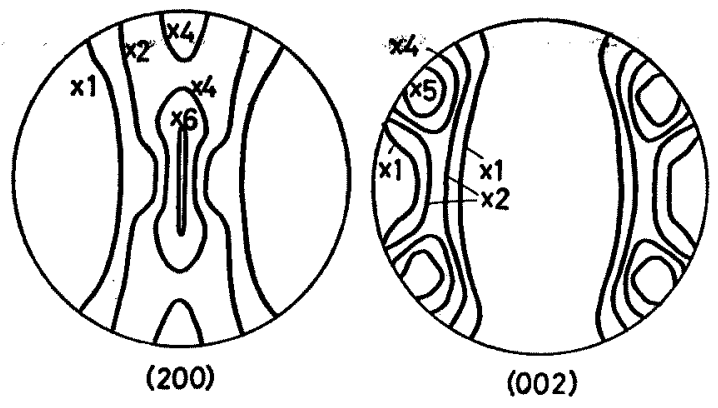

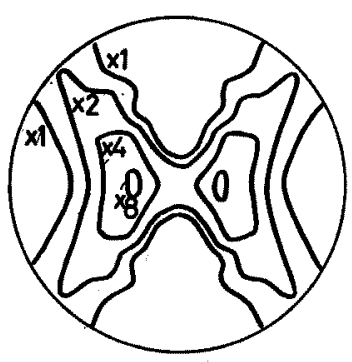

(020)

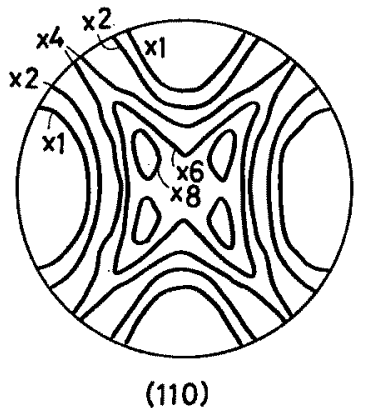

(110)

Fig. 7-5. (continued) 


\section{Specimen No. 6}
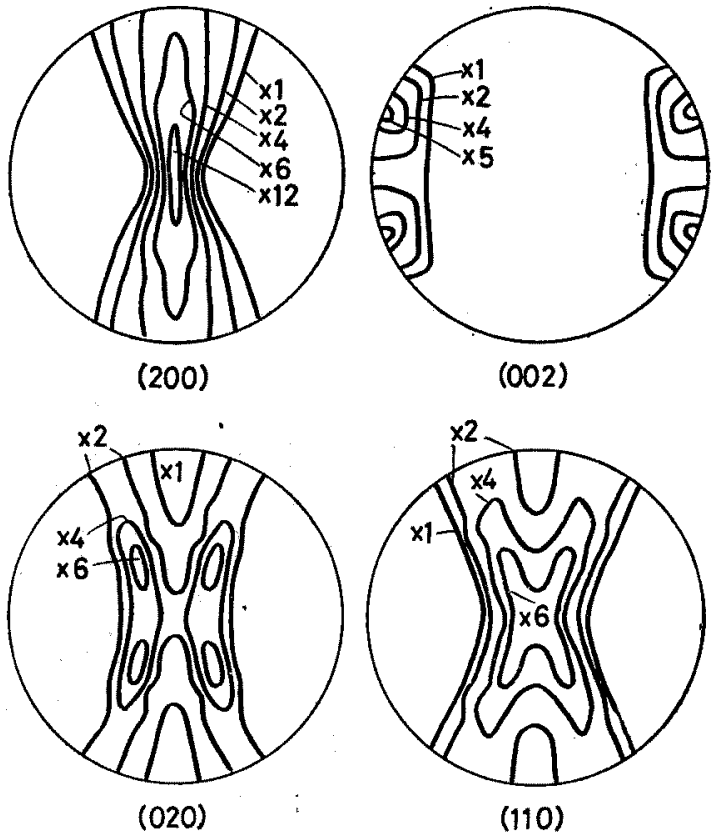

Fig. 7-6. (continued)
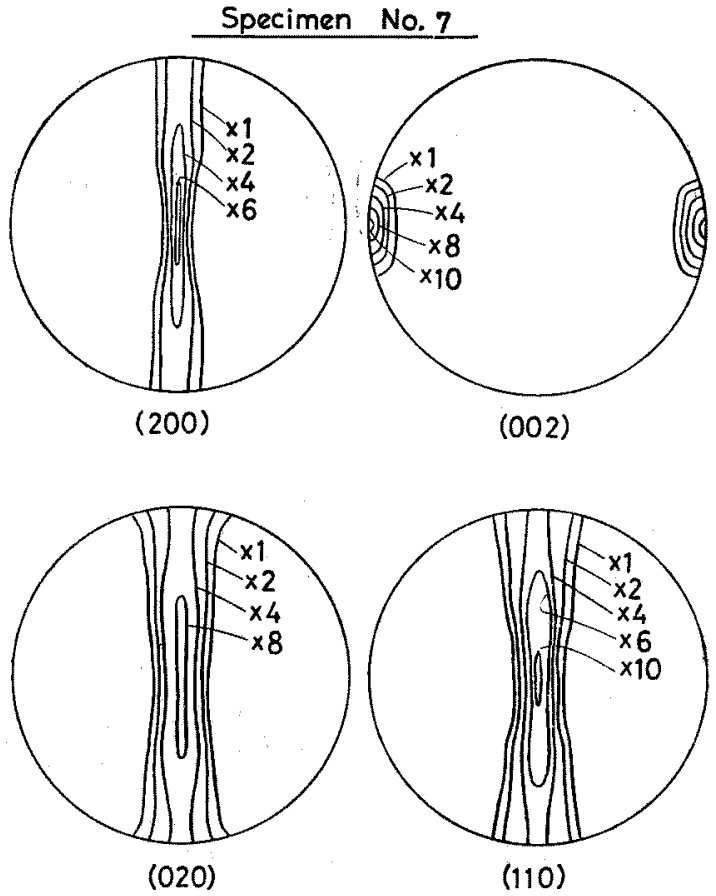

Fig. 7-7. (continued) 

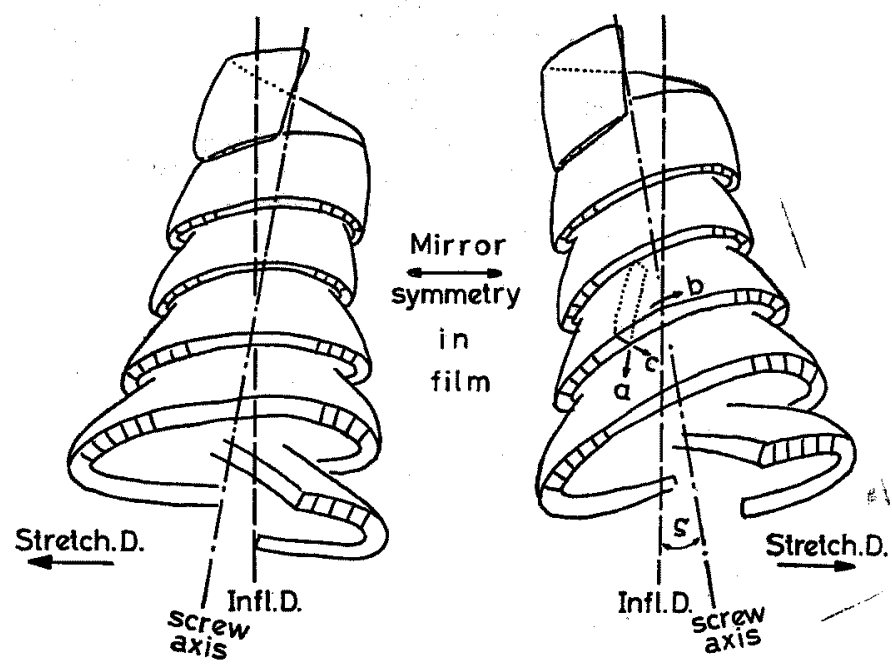

Fig. 8. Illustration of the shifting of screw axis to the inflation direction caused by the stretching perpendicular. The original idea of the screw dislocation structure has been proposed by Kobayashi et al. (Ref. 9)

Table 2. Biaxial orientation of three crystallographic axes of polyethylene crystallites in the stretching for transverse direction of highly $c$ axis oriented film.

\begin{tabular}{c|ccc|ccc|ccc}
\hline \multirow{2}{*}{ Specimen } & \multicolumn{3}{|c|}{$\overline{\cos ^{2} \Phi_{a}}$} & \multicolumn{3}{|c|}{$\overline{\cos ^{2} \Phi_{b}}$} & \multicolumn{3}{c}{$\overline{\cos ^{2} \Phi_{c}}$} \\
& & $y$ & $z$ & $x$ & $y$ & $z$ & $x$ & $y$ & $z$ \\
\hline No. 1 & 0.493 & 0.445 & 0.062 & 0.477 & 0.497 & 0.026 & 0.030 & 0.058 & 0.912 \\
No. 2 & .581 & .328 & .091 & .387 & .509 & .104 & .032 & .163 & .805 \\
No. 3 & .622 & .272 & .106 & .347 & .522 & .131 & .031 & .206 & .763 \\
No. 4 & .647 & .143 & .210 & .314 & .454 & .232 & .039 & .403 & .558 \\
No. 5 & .534 & .128 & .338 & .431 & .242 & .327 & .035 & .630 & .335 \\
No.6 & .529 & .114 & .357 & .444 & .148 & .408 & .027 & .738 & .235 \\
No. 7 & .528 & .087 & .385 & .458 & .017 & .525 & .014 & .896 & .090 \\
\hline
\end{tabular}

第1はラセン軸の張力方向へのシフトである。結晶 $b$ 軸はラセン軸の垂直方向で，初期のラセン軸まわりの回 轱関係を完全に保持しつつ, 引張りによるラセン軸のy 軸方向へのシフト飞従与（第 8 図）。

第 2 は $a, c$ 軸むまた $b$ 軸同様，ラセン軸まわりに回 䎐しながらラセン軸の方位变化に從うのであるが，この 变化烦並行して (100) 面で [001] 方向への塑性すべりが 優先して郝こりこのすべり面は変形とともに結晶 $b$ 軸 まっりに回転してフィルム面に近すきき， $a$ 軸はフィルム 法線からの平均配向角度を次第飞小さくし， $x$ 軸に平行 した成分の相詨量を增加する。これととるに $c$ 軸はラセ ン軸に平行汇配向する成分の相対量增加し，次第に明 瞪な (002) 極図形を認めることができるように変化す る。
変形過程の最終段階に打いては結晶 $c$ 軸は引張り軸 $y$ 飞濞近し， $a, b$ 軸はその垂直方向で任意の回転関係をと るに至るが，そのc軸は配向を僅が異にする領域が双 晶的な配置をとっているるのと思われる。このことは変 形の最終段階に括讨る $\overline{\cos ^{2} \Phi_{c, z}}$ そ $\overline{\cos ^{2} \Phi_{c, x}}$ の值の不 一致なことおょび得られた延伸物の引張り軸にそった 引晊き抵抗の大きいこと等機械的性質の点からも裹付け られた。

次に $c$ 軸高配向フィルムの横方向への自由幅延伸につ いて検討を行なった結果を述べる。

第 9 図炕示した扒のおのの延伸試料についてその結晶 主軸の配向保数を第 2 表に，またと机らの正三角形プロ ットを第 10 図にそれぞれ示した。

横延伸前には $c$ 軸を中心にした $a, b$ 軸の任意の回転関， 


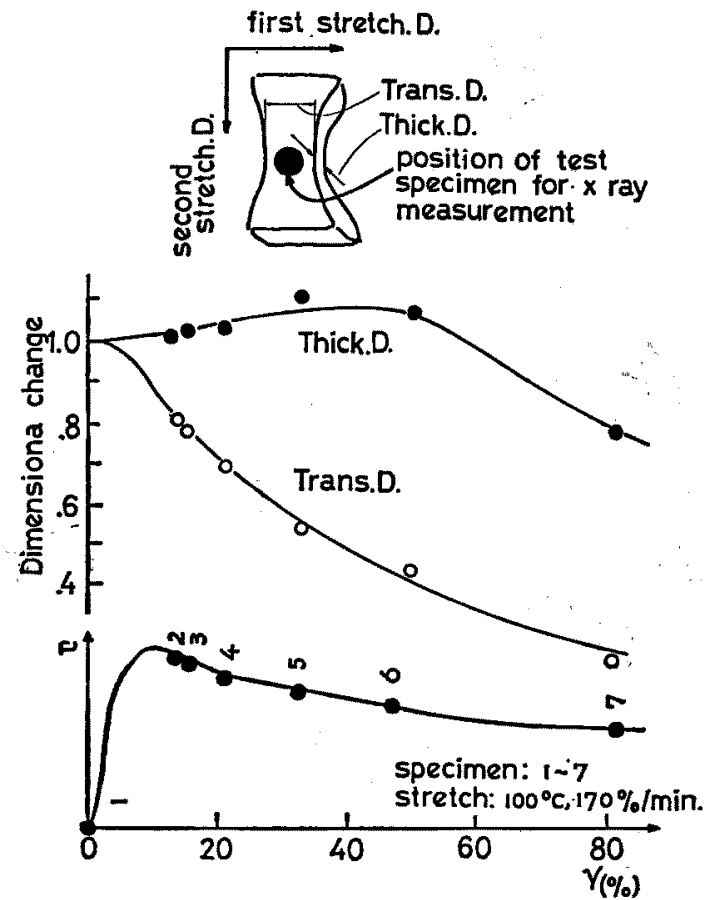

Fig. 9. Explanation for the test specimens used. (Experimental material Previously uniaxial stretched film)
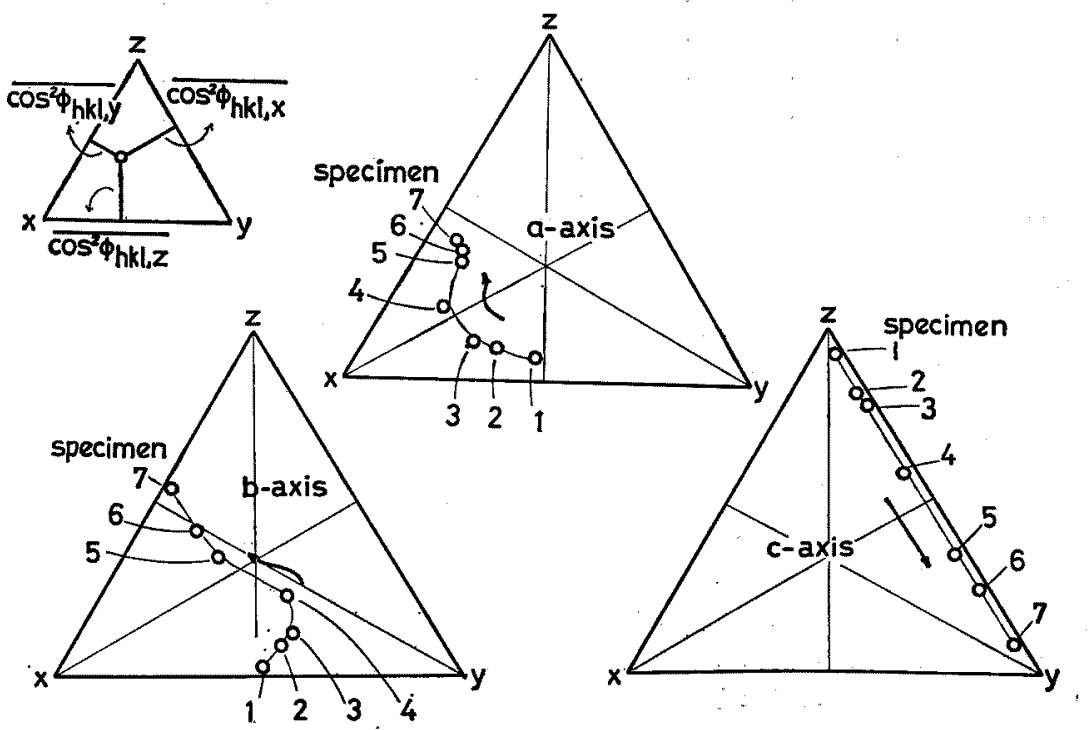

Fig.10. Equilateral triangle coordinates representing the degrees of biaxial orientations of crystallites in terms of the [three quantities of $\overline{\cos ^{2} \Phi_{i}}$. Test specimens : Highly $c$-axis oriented film and its stretched films for transverse direction. 
係（正しくは平均的にみて榇円状回転分布にあり棈円の 長軸が横方向）飞あるラメラは横方向への引張りによ $\eta$ ，その $a$ 軸の $\overline{\cos ^{2} \Phi_{x}}$ の値を， $b$ 軸の $\overline{\cos ^{2} \Phi_{y}}$ の値を それそれ增加さ出，多重配向 textureをとり，次に $z$ 軸に平行に配向した $c$ 軸が張力方向ヘシフトする。この $c$ 軸の变位は第 10 四の正三角形プロットにみられるよ らに, フイルム面に対して平行移動である。このよらに して $c$ 軸の主配向角度は初期の $\zeta=0^{\circ}$ から最終的には $90^{\circ}$ へと第 3 表のよう渐近する。特微的なことは第 12 因にみられるように，c軸の配向の分布が横延伸を通じ て方位角方向一散乱せず，第 3 表の主配向角度を中心に 高度の集中度を保っていることである。第 3 表の $c$ 軸主 配向角度 $\zeta を ，$ 第 2,3 図の固定座標 $\boldsymbol{z}$ と一致させるよ う $\Psi_{\varepsilon}$ について角度变换して $\Psi_{\xi}=0^{\circ}$ とし，(200）およ び (110) 回折の分布函数 $N_{\left(\varphi_{x}, y_{z^{\prime}}\right)}$ から式 5,6 を用い
Table 3. Center of orientation distribution of $c$-axes in terms of azimuthal angle

\begin{tabular}{c|c}
\hline Specimen & $\zeta$ \\
\hline 1 & $0^{\circ}$ \\
2 & $14.7^{\circ}$ \\
3 & $19.2^{\circ}$ \\
4 & $37.7^{\circ}$ \\
5 & $59.0^{\circ}$ \\
6 & $68.4^{\circ}$ \\
7 & $81.7^{\circ}$ \\
\hline
\end{tabular}

て二軸配向倸数を specimen No. 5 とついて求めた結果 概权

$$
\begin{aligned}
& \overline{\cos ^{2} \Phi_{x^{\prime}}}=0.038 \\
& \overline{\cos ^{2} \Phi_{y^{\prime}}}=0.094
\end{aligned}
$$
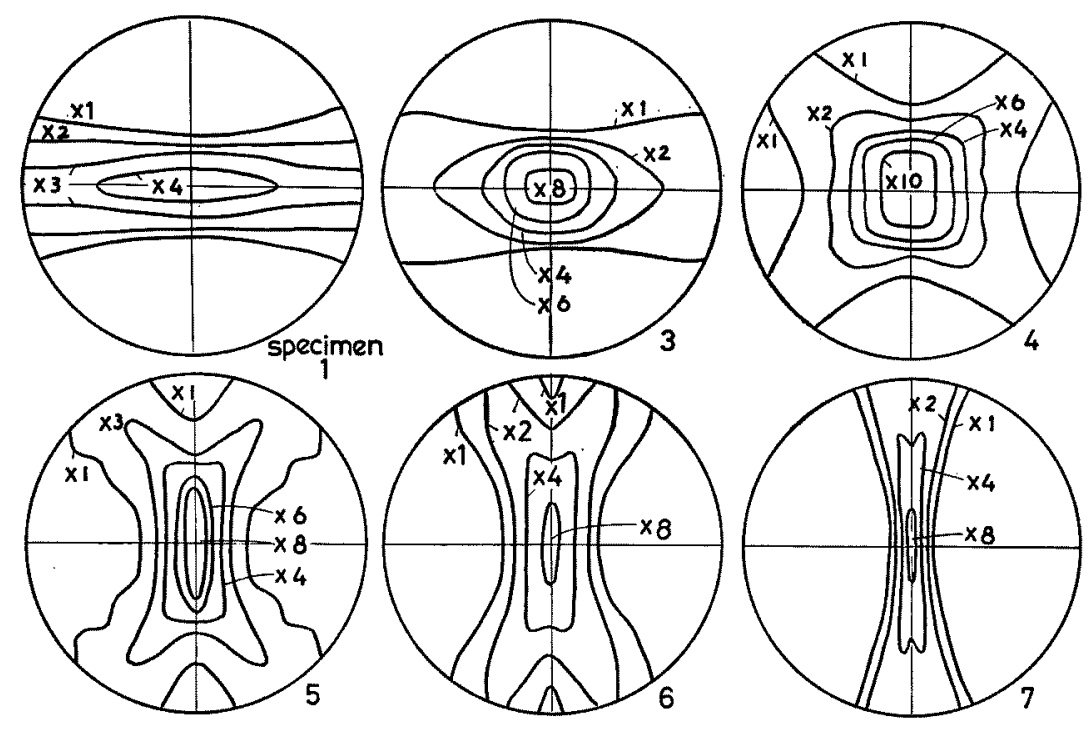

Fig.11. (200) Pole figures in the stretching for transverse direction of highly $c$-axis oriented film.
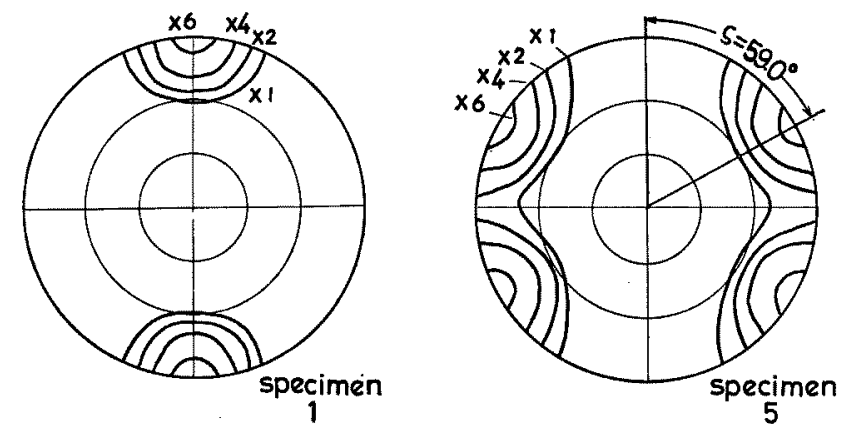

Fig. 12. (continued). (002) Pole Figures. 


$$
\overline{\cos ^{2} \Phi_{z^{\prime}}}=0.868
$$

であった。

この数値および变形の最終段階の結晶 3 主軸の二軸配 向俰数の值は，このよらにして延伸された構造物の延伸 組織が双晶的構造をとっているるのであることを暗示す るものである。結晶配向の測定は形態を規定するるので ないということを認識するるのであるが，結晶配向の観 点からこれらの系に拈ける結晶の塑性挙動に伴う集合組 織の発生の素過程について整定的な結論を提示するすの である。

$$
\text { 文 献 }
$$

1) 2.W. Wilchinsky ; J. Applied Phys., 31, 543 (1961)
2) C. R. Desper and R.S.Stein ; J. Applied Phys., 37, 3990 (1966)

3) B. F. Decker, E. T. Asp and D. Harker ; J.Applied Phys., 19, 388 (1948)

4) L. G. Schulz ; J.Applied Phys., 20, 1033 (1949)

5) T. Takahashi and I. Sato ; Polymer J., 1, 296 (1970),

6) D. R. Holmes, R. G. Miller, R. P. Palmer and C. W. Bunn ; Nature, 171, 1104 (1953)

7) K. Kobayashi ; in Polymer Single Crystal, P.H. Geil, Ed. (Interscience, New York, 1963) p. $465 \sim 475$

8) A.Keller ; Nature, 174, 926 (1954)

9) K. Kobayashi and T. Nagasawa ; J. Polymer Sci., Part C, No. 15, 163 (1966). 